CORRECTION

\title{
Correction to: Editorial
}

\section{Curie Virág ${ }^{1}$}

Published online: 25 November 2021

(c) Springer Nature B.V. 2021

\section{Correction to: Ethical Theory and Moral Practice https://doi.org/10.1007/s10677-021-10254-9}

The original version of the article unfortunately contained an error.

The word "world" was mistakenly changed to "word" in the phrase "world of social interaction" in the first page of the article (start of the 3rd paragraph).

The original article has been corrected.

Publisher's Note Springer Nature remains neutral with regard to jurisdictional claims in published maps and institutional affiliations.

The original article can be found online at https://doi.org/10.1007/s10677-021-10254-9

Curie Virág

Curie.Virag@ed.ac.uk

1 University of Edinburgh, Edinburgh, UK 